\title{
Aboveground and below-ground carbon allocation of summer rape under elevated $\mathrm{CO}_{2}$ and air temperature
}

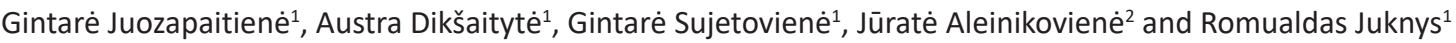 \\ ${ }^{1}$ Vytautas Magnus University, Vileikos street 8, LT-44404, Kaunas, Lithuania \\ ${ }^{2}$ Aleksandras Stulginskis University, Studentu street 11, LT-53361, Akademija, Lithuania \\ e-mail: gintare.juozapaitiene@vdu.lt
}

\begin{abstract}
In studies on plant responses to climate change more attention has been given to aboveground processes although carbon input by plants into the soil is a major flux in the global carbon cycle. The objective of study was to investigate the effects of elevated $\mathrm{CO}_{2}$ and temperature on carbon allocation and partitioning in different parts of plant, soil, and microbial biomass. An experiment was conducted on summer rape (Brassica napus L.) under increased levels of air temperature and atmospheric $\mathrm{CO}_{2}$ in controlled environment chambers. Results showed that the amount of leaf, stem and root carbon statistically significantly increased under elevated $\mathrm{CO}_{2}$ and temperature conditions. Microbial biomass carbon significantly increased by $11.2 \%$ and $13.5 \%$ under elevated $\mathrm{CO}_{2}$ and elevated $\mathrm{CO}_{2}$ and temperature, respectively, although soil carbon under both treatments decreased. It is concluded that carbon allocation is controlled under different climate conditions; however, elevated $\mathrm{CO}_{2}$ and temperature together will have a more significant effect for carbon allocation to different plant parts and microbial biomass carbon compared to elevated $\mathrm{CO}_{2}$ alone.
\end{abstract}

Key words: carbon allocation, soil carbon, microbial biomass carbon, leaf area, summer rape

\section{Introduction}

Studies on plant responses to increased atmospheric $\mathrm{CO}_{2}$ concentration and elevated temperatures have become abundant in the last 20 years (Franks et al. 2013). Allocation of carbon to different plant organs is central in this discussion and provides a mechanism by which plants can adapt to changes in the environment (Chaves et al. 2002). Carbon partitioning varies with plant development stage (reflecting changing priorities) but also depends on species-specific strategies (Weiner 2004), such as preferred allocation in below-ground storage compounds (Kuzyakov and Domanski 2000), responses to environmental conditions, e.g. drought or other stress factors (Sanaullah et al. 2012). Although usually more attention is given to aboveground processes, carbon input by plants into the soil is a major flux in the global carbon cycle and is crucial not only for carbon sequestration, but also for maintenance of soil fertility, ecosystem stability, and functions (Pausch and Kuzyakov 2017).

Below-ground processes play a key role in global carbon cycle because they regulate the storage of large quantities of carbon and are potentially very sensitive to direct and indirect effects of elevated $\mathrm{CO}_{2}$ and temperature (Pendall et al. 2004). Elevated $\mathrm{CO}_{2}$ increases carbon supply to below-ground parts of plants, whereas warming is likely to increase respiration and decomposition rates, leading to speculations that these effects will moderate one another (Pendall et al. 2004). The variations in plant carbon allocation suggest there could be significant differences in plant carbon allocation across crop types, climatic zones, and soil types. The differences are certainly critical in the eventual deposition of plant carbon into soil carbon pools and can be used to select crop varieties with superior carbon sequestration potential (Mathew et al. 2017). Therefore, it is important to understand the carbon input to different parts (root vs. shoot) to strategize options intended to increase soil organic carbon (Rasse et al. 2005). Additionally, microbial biomass has been used as a sensitive indicator of alteration patterns in soil organic matter (Balota et al. 2003). If climate change alters soil microbial communities and this change determines plant species establishment and growth, then ecosystem responses will be dependent on the interactions between plants and soil communities (Classen et al. 2015).

The objective of this study was to investigate the effects of elevated $\mathrm{CO}_{2}$ and temperature on biomass accumulation and carbon content in different parts of Brassica napus, soil carbon, and microbial biomass, to investigate the physiological and morphological responses of the crop to different climatic treatments and to ascertain whether elevated $\mathrm{CO}_{2}$ and elevated $\mathrm{CO}_{2}$ and temperature, projected by the end of this century, would differentially affect carbon allocation to different plant parts. 


\section{Material and methods \\ Plant material and growth conditions}

The experiment was conducted in the growth chambers in the Vytautas Magnus University. Summer rape (Brassica napus L.) was chosen because it is one of the major crops of the EU27 member states (Donatelli et al. 2015) and one of the most popular crops in Lithuania. Seeds of summer rape (Brassica napus L. var. 'Fenja') (15 seeds per container) were sown in 3 I plastic containers (height $10.6 \mathrm{~cm}$ ) containing a growth substrate composed of a mixture of field soil (the soil was taken from ASU Training Farm, Kaunas District), perlite, and fine sand (5:3:2 by volume). In the control chamber plants were grown under conditions of current climate-an average day/night temperature of $21 / 14^{\circ} \mathrm{C}$ and $400 \mu \mathrm{mol} \mathrm{mol}^{-1}$ of $\mathrm{CO}_{2}$ (CON). Elevated $\mathrm{CO}_{2}$ and temperature (day/night temperature of $25 / 18^{\circ} \mathrm{C}$ and $800 \mathrm{ppm}$ of $\mathrm{CO}_{2}, \mathrm{ETC}$ ) and elevated $\mathrm{CO}_{2}$ (day/night temperature of $21 / 14{ }^{\circ} \mathrm{C}$ and $800 \mathrm{ppm}$ of $\mathrm{CO}_{2}, \mathrm{EC}$ ) treatments started when the seedlings of summer rape were germinated, and lasted for 4 weeks. The elevated temperature and $\mathrm{CO}_{2}$ concentrations were increased to the level in accordance with the climate change scenario for Lithuania (Juknys et al. 2017). The pre-set values of the air temperature in the growth chambers were controlled manually at each of the growth chambers (Emerson Network Power S.r.l., Italy, model No. S06UC021V300020FX051260). The concentration of $\mathrm{CO}_{2}$ was manipulated automatically by controlling the amount of injected $\mathrm{CO}_{2}$ gas and chamber conditioner. The climate program was controlled by the IGSS 9-13175 software. The following stable conditions were maintained in all chambers: a photoperiod of $14 \mathrm{~h}$, relative humidity of 50/60\%, and $226 \mu \mathrm{mol} \mathrm{m}^{2} \mathrm{~s}^{-1}$, on average, photon flux density of photosynthetically active radiation (PAR). A nutrient supply corresponding to $120 \mathrm{~kg}$ $\mathrm{N}$ ha ${ }^{-1}$ was used after sowing the seeds. Additional fertilization with a complex nutrient (NPK 12-11-18 + microelements) solution, increasing the $\mathrm{N}$ level to $180 \mathrm{~kg} \mathrm{~N} \mathrm{ha}^{-1}$, was applied in the middle of treatments ( 2 weeks after the seedlings were germinated). The pots in the chambers were watered sufficiently and regularly. All treatments were run in three replicates (three pots per chamber). Avoiding edge effects, the pots were rotated every second day.

\section{Photosynthesis rate and leaf area measurement}

Photosynthetic rates $\left(\mathrm{Pr}, \mu \mathrm{mol} \mathrm{CO} \mathrm{m}^{2} \mathrm{~s}^{-1}\right)$ were measured with a portable photosynthesis system LI-6400 (LI-COR, USA) equipped with a $6 \mathrm{~cm}^{2}$ leaf chamber. Photosynthetic rates were recorded automatically for approximately 5 minutes every $3 \mathrm{~s}$ when Pr reached the steady state level. The measurements were made on the most recent fully expanded leaves (i.e. one leaf per plant) of intact plants (randomly chosen plants were measured). Three plants per pot (the average of them was taken for statistical analysis) and three pots per treatment were measured ( $n=$ 3) under ambient, elevated $\mathrm{CO}_{2}$ and elevated $\mathrm{CO}_{2}$ and temperature climate treatments from 10:00 $\mathrm{h}$ to 15:00 $\mathrm{h}$ on the last day of the experiment. During the measurements, leaf chamber conditions were controlled at 400 or 800 $\mu \mathrm{mol} \mathrm{mol}{ }^{-1} \mathrm{CO}_{2}$, and 21 or $25^{\circ} \mathrm{C}$ (block temperature), according to the climate treatments. Airflow rate through the assimilation chamber was maintained at $500 \mu \mathrm{mol} \mathrm{s}{ }^{-1}$. The water vapour concentration of air entering the leaf chamber was not controlled and tracked ambient conditions. Relative humidity was $51 \pm 0.9 \%$ in CON, $62 \pm 3.5 \%$ in EC, and $39 \pm 1.6 \%$ in ETC treatment (mean $\pm \mathrm{SE}$ ). PAR outside the leaf chamber was $226 \pm 4.0 \mu \mathrm{mol} \mathrm{m}^{2} \mathrm{~s}^{-1}$, on average, under the different climate conditions.

The measurements of leaf area were carried out on the last day of treatment. The leaf area per plant (three replicates per treatment) was measured with a scanner (CanoScan 4400F, Canon, USA) and then the leaf area was determined by GIMP 2.8 software. Leaf area ratio (LAR) was calculated as the ratio of leaf area and total plant weight.

\section{Dry weight and carbon content measurements}

Samples of plant leaves, stems, and roots were dried in an air-forced oven at $70^{\circ} \mathrm{C}$ until a constant dry weight was obtained (at least 72 hours). Soil samples were also taken at the end of the experiment. The samples were air dried at room temperature and sieved through $2 \mathrm{~mm}$ mesh to remove roots and plant remains. The dried samples of shoots, roots, and soil were ground to a fine powder with a mill (Retsch HM400, Germany).

Organic carbon content (\%) in dried plant and soil samples was analyzed with a Shimadzu TOC-V solid sample module SSM-5000A. The root carbon stock (Rcs) and shoot carbon stock (Scs) were defined as the total amount of carbon (g) in dry weight measured in the corresponding plant parts. Microbial biomass carbon was determined by a chloroform fumigation direct extraction method (Beck et al. 1997). 


\section{Data analysis}

Statistical analyses were carried out using STATISTICA 8 software. Mean values of the parameters (plant photosynthetic rate $(\mathrm{Pr}), \mathrm{LAR}$, plant dry weight, carbon content of leaf, stem and root, the ratio of root carbon stock and shoot carbon stock (Rcs/Scs), microbial biomass carbon, and soil carbon) and their standard errors of mean $( \pm S E)$ were calculated. The Mann-Whitney U-test was used to estimate the difference between parameters under different climatic conditions. Spearman rank correlation was used to determine the strength of relationships between variables.

\section{Results}

\section{Changes in plant photosynthesis and dry weight}

The analysis of photosynthesis and carbon allocation is useful for understanding how the plants will respond to climate change, including the impact on biomass production. Changes in total plant dry weight and dry weight of different parts of plant, LAR, and Pr are presented in Figure 1. Total plant dry weight was significantly higher under climate treatment conditions (elevated $\mathrm{CO}_{2}[\mathrm{EC}]$ and elevated $\mathrm{CO}_{2}$ and temperature [ETC]) in comparison with the ambient climate (CON) $(p<0.05)$ (Fig. 1.A). ETC significantly increased the dry mass of plants on average by $142 \%(p<0.05)$. Elevated $\mathrm{CO}_{2}$ and temperature had the highest positive effect on leaf dry weight (Fig. 1.A): the amount of leaf dry weight increased by $142 \%(p<0.05)$ under ETC compared to CON conditions. Both EC and ETC significantly decreased LAR: by $30 \%$ and by $46 \%$, respectively, compared to CON (Fig. 1.B). The photosynthetic rate was significantly higher under EC and ETC, compared to CON $-29 \%$ and $75 \%$, respectively $(p<0.05$, Fig. 1.C).
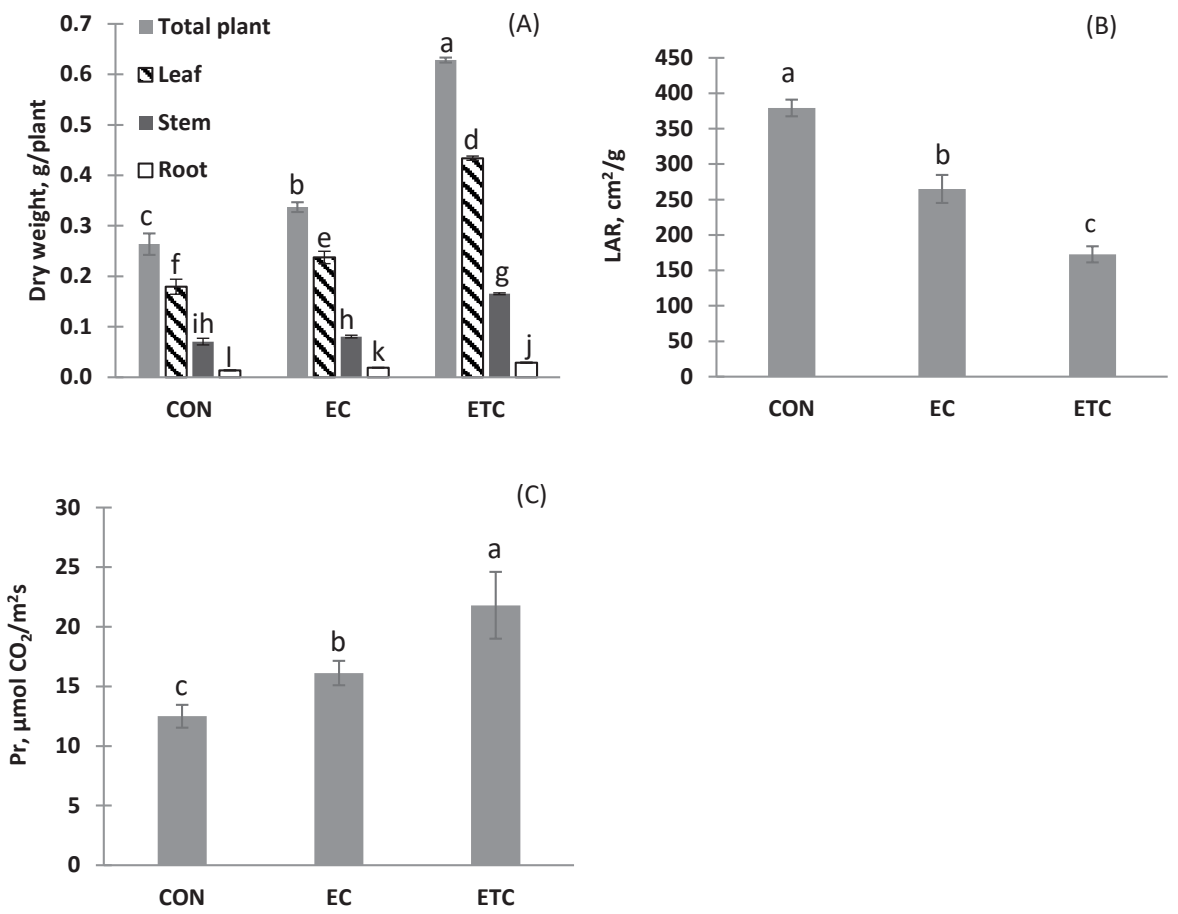

Fig. 1. Photosynthesis parameters and morphological parameters: A. Total plant dry weight and weight of different parts of plant; B. Leaf area ratio (LAR); C. Photosynthetic rate (Pr). Different letters indicate significant differences among treatments $(p<0.05)$ based on U-test. $\mathrm{CON}=$ ambient temperature and $\mathrm{CO}_{2}, \mathrm{EC}=$ elevated $\mathrm{CO}_{2}, \mathrm{ETC}=$ elevated temperature and $\mathrm{CO}_{2}$

\section{Carbon content in different plant parts}

The carbon content increased in all plant parts under ETC conditions, but there was almost no changed under EC. Carbon content in leaf and root was significantly higher by $3 \%(p<0.05)$ and by $6 \%(p<0.05)$, respectively, under ETC, compared to ambient climate conditions (Fig. 2.A). Also, elevated $\mathrm{CO}_{2}$ and temperature have had the highest positive effect on stem carbon: the content of stem carbon increased by $19 \%(p<0.05)$ under ETC compared to CON conditions. However, EC had less impact on stem carbon changes-its amount increased only by $2 \%$ compared to ambient climate conditions $(p>0.05)$. Correlation analysis showed a significant positive relationship between photosynthesis, plant biomass and carbon content in different plant parts $(p<0.05)$. While photosynthesis increased, plant biomass $(r=0,88, p<0.05)$, carbon content in plant leaf $(r=0.72, p<0.05)$, stem $(r=0,85, p<0.05)$, and root $(r=0,68, p<0.05)$ also increased. 

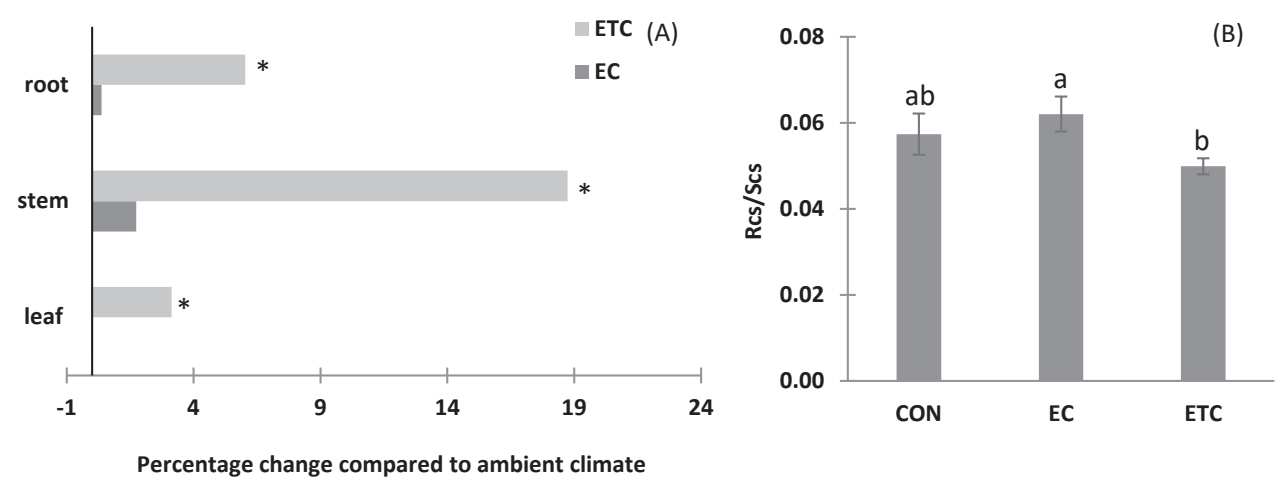

Fig. 2. A. Change of carbon content in different plant parts (\%) under changed climate conditions compared with ambient climate. $(*$ - statistically significant difference, compared to ambient climate conditions at $P<0.05$ ). B. The ratio of root carbon stock (Rcs) and shoot carbon stock (Scs) under different climate conditions. Different letters indicate significant differences among treatments $(p<0.05)$ based on U-test. $\mathrm{CON}=$ ambient temperature and $\mathrm{CO}_{2}, \mathrm{EC}=$ elevated $\mathrm{CO}_{2}, \mathrm{ETC}=$ elevated temperature and $\mathrm{CO}_{2}$

To assess carbon allocation to roots under different climate conditions, the ratio of root carbon stock to shoot carbon stock (Rcs/Scs) was determined (Fig. 2.B). Under EC climate conditions, Rcs/Scs ratio increased by $8 \%(p>0.05)$; while under ETC conditions, the Rcs/Scs ratio decreased by $13 \%(p>0.05)$ compared to ambient climate conditions. The Rcs/Scs ratio decreased under ETC conditions, because the increase in Scs was relatively much higher than the increase in Rcs under ETC conditions.

\section{Microbial biomass carbon and soil carbon}

Microbial biomass carbon increased by $11.2 \%(p<0.05)$ and by $13.5 \%(p<0.05)$ under EC and ETC conditions, respectively, although soil carbon decreased by $5 \%(p>0.05)$ and by $6 \%(p>0.05)$, respectively, compared to ambient climate conditions (Fig. 3). There was no significant correlation between microbial biomass carbon and soil carbon, but it was estimated that microbial biomass carbon significantly correlated with plant root biomass. While plant root biomass increased, microbial biomass carbon also was statistically significantly higher $(r=0.71, p<0.05)$. Soil carbon was negatively correlated with the carbon content in plant stem, stem biomass, and leaf biomass. While plant stem carbon $(r=-0.72, p<0.05)$, stem biomass $(r=-0.7, p<0.05)$, leaf biomass $(r=-0.74, p<0.05)$ increased, soil carbon significantly decreased.

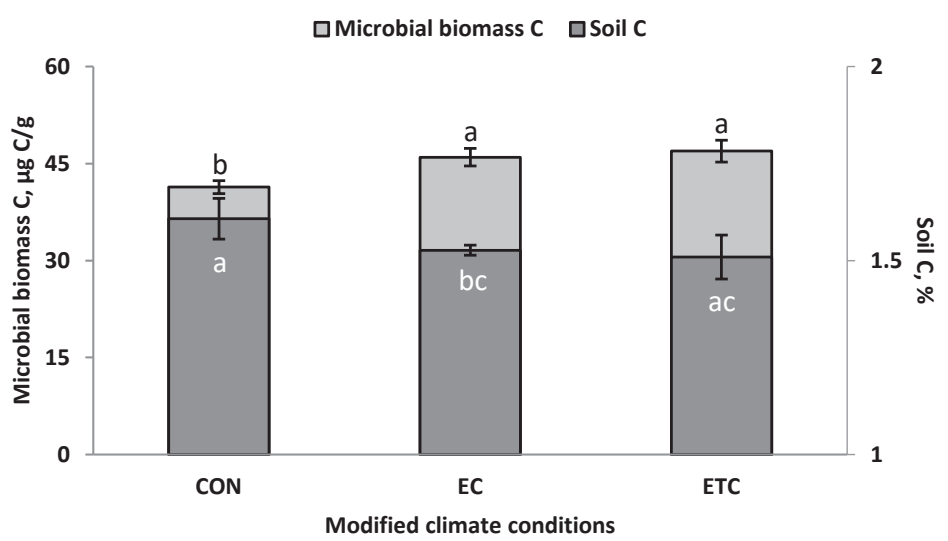

Fig. 3. Microbial biomass carbon and soil carbon under modified climate conditions (mean \pm SE). Different letters indicate significant differences among treatments $(p<0.05)$ based on U-test. Treatments: $\mathrm{CON}=$ ambient temperature and $\mathrm{CO}_{2}, \mathrm{EC}=$ elevated $\mathrm{CO}_{2}, \mathrm{ETC}=$ elevated temperature and $\mathrm{CO}_{2}$ 


\section{Discussion}

The results showed that the photosynthetic rate under elevated $\mathrm{CO}_{2}$ was $29 \%(p<0.05)$ higher, and under elevated $\mathrm{CO}_{2}$ and temperature, $75 \%(p<0.05)$ higher compared to ambient climate conditions. With the reference to Ainsworth and Long (2005), the elevated $\mathrm{CO}_{2}$ stimulates photosynthetic carbon assimilation rate by an average of $31 \%$, which is similar to the current experiment. This stimulation of photosynthesis in $\mathrm{C}_{3}$ plants such as Brassica napus due to elevated $\mathrm{CO}_{2}$ occurs because Rubisco is $\mathrm{CO}_{2}$ substrate-limited at ambient $\mathrm{CO}_{2}$ (Long et al. 2004, Tcherkez et al. 2006). Elevated $\mathrm{CO}_{2}$ enhances photosynthesis and, in turn, dry matter accumulation increases (Lawlor and Mitchell 2000, Ainsworth and Long 2005, Taub and Wang 2013). This is in accordance with the current experiment results; elevated $\mathrm{CO}_{2}$ increased the biomass of Brassica napus by 1.3 times, and elevated both $\mathrm{CO}_{2}$ and temperature by 2.4 times compared to ambient climate conditions. Positive interaction between elevated $\mathrm{CO}_{2}$ and increased air temperature on photosynthesis and biomass production of $\mathrm{C}_{3}$ plants has also been reported in other studies (Vu 2005, Borjigidai et al. 2006, Alonso et al. 2009, Yoon et al. 2009, Juknys et al. 2011, 2012, Kacienè et al. 2017). This positive interaction between elevated $\mathrm{CO}_{2}$ and temperature is explained by increased optimal temperature for plant growth (Long and Drake 1991, McMurtrie and Wang 1993) and net photosynthesis (Bernacchi et al. 2006, Alonso et al. 2009) under elevated $\mathrm{CO}_{2}$. According to Long and Drake (1991), the optimal temperature for many $\mathrm{C}_{3}$ plants may increase by approximately $5{ }^{\circ} \mathrm{C}$, as $\mathrm{CO}_{2}$ increases by $300 \mu \mathrm{mol} \mathrm{mol}{ }^{-1}$, as was the case in the current experiment.

However, an increase of the photosynthetic rate, which often is the result of increased $\mathrm{CO}_{2}$, is not necessarily directly linked to higher crop production and yield (Frenck et al. 2011). As reported by Frenck et al. (2011), only in one of four Brassica napus cultivar ('Bolero') the biomass was significantly increased under elevated $\mathrm{CO}_{2}$. It should be realized that there is no $1: 1$ translation of a photosynthetic $\mathrm{CO}_{2}$ response into a growth response, as is highlighted in the review by Körner (2006). The discrepancy between the almost uniform stimulation of leaf photosynthetic rates in proportion to a rise in $\mathrm{CO}_{2}$ concentration and rather variable growth responses, from zero to a large positive effect, has confounded researchers for as long as this research has been conducted, and that puzzle has not been resolved (Nowak et al. 2004). In addition, it is well known that the initial stimulation of photosynthetic rate by elevated $\mathrm{CO}_{2}$ for most $\mathrm{C}_{3}$ plants is temporal, and slows with future exposure, particularly under relatively long-term impact of elevated $\mathrm{CO}_{2}$, and stabilizes at a lower level, the phenomenon known as downregulation (Kant et al. 2012, Xu et al. 2015). Because photosynthetic downregulation may be both plant development and species-ecotype dependent ( $\mathrm{Li}$ et al. 2008, Aranjuelo et al. 2009, Kaplan et al. 2012), the extent of the increase in photosynthesis under elevated $\mathrm{CO}_{2}$ conditions varies greatly among the species and even different varieties and functional groups of plants (Long et al. 2004, Leakey et al. 2009). Global changes in photosynthetic uptake could lead to a rapid response from short-lived $C$ pools (such as foliage, fine roots, and litter) or a prolonged response from long-lived $C$ pools (such as woody biomass and soil C) with very different outcomes on ecosystem sourcesink behavior (Bloom et al. 2016).

Short-term C assimilation is typically linked to growth, which contradicts evidence that show significant temporal lags between assimilation and leaf/stem growth (Zweifel et al. 2006, Gough et al. 2009, Richardson et al. 2013). Results showed that carbon content increased in all Brassica napus parts under elevated $\mathrm{CO}_{2}$ and temperature conditions, but it almost was unchanged under elevated $\mathrm{CO}_{2}$ compared to ambient climate conditions. Leaf carbon increased only by $3 \%(p<0.05)$ under elevated $\mathrm{CO}_{2}$ and temperature conditions, which was probably due to rapid carbon loss by leaf respiration and carbon export to other pools (Hill et al. 2007, Wu et al. 2010). Elevated $\mathrm{CO}_{2}$ and temperature had the highest positive effect on stem carbon-the amount of stem carbon increased by $19 \%(p<0.05)$ compared to ambient climate conditions. Also, the Rcs/Scs analysis showed the amount of carbon was increased in shoots under elevated temperature and $\mathrm{CO}_{2}$ conditions. According to Mathew et al. (2017), generally, all plants allocate more carbon in the shoots, showing that roots are relatively weaker carbon sinks compared to shoots. Shoot carbon stocks are higher than root carbon stocks because carbon is only exported to other sinks when the supply exceeds local demand (Ludewig and Flügge 2013). Also, Pausch and Kuzyakov (2017) showed that the main part of assimilated $\mathrm{C}$ remains aboveground and is used for shoot respiration and for shoot biomass production or $\mathrm{C}$ storage. According to results of the current experiment, elevated $\mathrm{CO}_{2}$ increased the carbon content in both roots and shoots, especially in ETC, compared to ambient climate conditions. However, the $\mathrm{Rcs} / \mathrm{Scs}$ decreased in ETC due to higher relative increase in carbon in the shoots. The reason may be that $\mathrm{CO}_{2}$ enrichment increases carbon partitioning to the rapidly cycling carbon pools (below-ground) and root turnover due to increased demand for below-ground resources (Hungate et al. 1997, Ge et al. 2012). Rhizodeposition consists of a continuous flow of carbon-containing compounds from the roots to the soil (Gougoulias et al. 2014). Increased atmospheric $\mathrm{CO}_{2}$ stimulates photosynthesis (Dijkstra et al. 2005, Hungate et al. 2006) and the release of root exudates, which in turn, means more labile carbon available for microbial decomposition and respiration (Ainsworth and Long 2005, Heath et al. 2005, Rayner et al. 2005, Friedlingstein et al. 2006, Hungate et al. 2006). 
Microbial biomass carbon increased under elevated $\mathrm{CO}_{2}$ and elevated $\mathrm{CO}_{2}$ and temperature conditions compared to the ambient climate in the current experiment, although soil carbon decreased under both climatic treatments compared to ambient climate. Jackson et al. (2017) indicated increases in carbon uptake by plants under elevated atmospheric $\mathrm{CO}_{2}$ might be partially offset by the accelerated loss of soil carbon due to plant-induced stimulation of microbial decomposition. Also, the decline in soil carbon may be driven by changes in soil microbial composition and activity. Soils exposed to elevated $\mathrm{CO}_{2}$ have higher relative abundances of fungi and higher activities of a soil carbon degrading enzyme, which led to more rapid rates of soil organic matter degradation than soils exposed to ambient $\mathrm{CO}_{2}$ (Carney et al. 2007). Allison et al. (2010) concluded, that the soil carbon response to climate warming depends on the efficiency of soil microbes in using carbon, however according to Pausch and Kuzyakov (2017), total carbon allocated below-ground also depends on photosynthetic intensity.

\section{Conclusion}

The analysis of photosynthesis and carbon allocation is useful to ascertain how the plants will respond to climate change, including the impact on biomass production. The objective of this study was to investigate the effect of climate change for carbon allocation in different parts of the plant, soil carbon, and microbial biomass carbon and to investigate physiological and morphological responses of crop Brassica napus to different climatic conditions. Results show increased biomass allocation in all plant parts under elevated $\mathrm{CO}_{2}$ in both temperature treatments, but effects of $\mathrm{CO}_{2}$ on crop and soil carbon contents differed. Stem carbon of the crop was most positively affected $(19 \%)$ by elevated $\mathrm{CO}_{2}$ and temperature, while exposure to $\mathrm{CO}_{2}$ alone had almost no effect on the amount of carbon in different plant parts. Soil carbon decreased under elevated $\mathrm{CO}_{2}$ and elevated $\mathrm{CO}_{2}$ and temperature conditions, and it was estimated that the decline in soil carbon was driven by changes in soil microbial composition and activity. Microbial biomass carbon increased statistically significantly by $11.2 \%$ and by $13.5 \%$ under elevated $\mathrm{CO}_{2}$ and elevated $\mathrm{CO}_{2}$ and temperature conditions, respectively. Physiological and morphological responses of crop Brassica napus to different climatic treatments showed stimulation of plant growth. Accelerated plant growth was shown by higher plant dry weight and increased photosynthetic rate.

\section{Acknowledgements}

This research was funded by a grant (No. SIT-8/2015) from the Research Council of Lithuania.

\section{References}

Ainsworth, E.A. \& Long, S.P. 2005. What have we learned from 15 years of free-air $\mathrm{CO}_{2}$ enrichment (FACE)? A meta-analytic review of the responses of photosynthesis, canopy properties and plant production to rising $\mathrm{CO}_{2}$. New Phytologist 165: $351-372$. https://doi.org/10.1111/j.1469-8137.2004.01224.x

Allison, S.D., Wallenstein, M. \& Bradford, M.A. 2010. Soil-carbon response to warming dependent on microbial physiology. Nature Geoscience 3: 336-340. https://doi.org/10.1038/ngeo846

Alonso, A., Perez, P. \& Martinez-Carrasco, R. 2009. Growth in elevated $\mathrm{CO}_{2}$ enhances temperature response of photosynthesis in wheat. Physiologia Plantarum 135: 109-120. https://doi.org/10.1111/j.1399-3054.2008.01177.x

Aranjuelo, I., Pardo, A., Biel, C., Save, R., Azcón-Bieto, J. \& Nogues, S. 2009. Leaf carbon management in slow-growing plants exposed to elevated $\mathrm{CO}_{2}$. Global Change Biology 15: 97-109. https://doi.org/10.1111/j.1365-2486.2008.01829.x

Balota, E.L., Colozzi-Filho, A., Andrade, D.A. \& Dick, R.P. 2003. Microbial biomass in soils under different tillage and crop rotation systems. Biology and Fertility of Soils 38: 15-20. https://doi.org/10.1007/s00374-003-0590-9

Beck, T., Joergensen, R.G., Kandeler, E., Makeschin, F., Nuss, E., Oberholzer, H.R. \& Scheu, S. 1997. An inter-laboratory comparison of ten different ways of measuring soil microbial biomass C. Soil Biology and Biochemistry 29: 1023-1032. https://doi. org/10.1016/S0038-0717(97)00030-8

Bernacchi, C.J., Leakey, A.D.B., Heady, L.E., Morgan, P.B., Dohleman, F.G., McGrath, J.M., Gillespie, K.M., Wittig, V.E., Rogers, A., Long, S.P. \& Ort, D.R. 2006. Hourly and seasonal variation in photosynthesis and stomatal conductance of soybean grown at future $\mathrm{CO}_{2}$ and ozone concentrations for 3 years under fully open-air field conditions. Plant, Cell and Environment 29: $2077-2090$. https://doi.org/10.1111/j.1365-3040.2006.01581.x

Bloom, A.A., Exbrayat, J., Velde, I., Feng, L. \& Williams, M. 2016. The decadal state of the terrestrial carbon cycle: Global retrievals of terrestrial carbon allocation, pools, and residence times. Proceedings of the National Academy of Sciences of the USA 113: 1285-1290. https://doi.org/10.1073/pnas.1515160113

Borjigidai, A., Hikosaka, K., Hirose, T., Hasegawa, T., Okada, M. \& Kobayashi, K. 2006. Seasonal changes in temperature dependence of photosynthetic rate in rice under a free-air $\mathrm{CO}_{2}$ enrichment. Annals of Botany 97: 549-557. https://doi.org/10.1093/aob/mcl001

Carney, K.M., Hungate, B.A., Drake, B.G. \& Megonigal, J. P. 2007. Altered soil microbial community at elevated $\mathrm{CO}_{2}$ leads to loss of soil carbon. Proceedings of the National Academy of Sciences of the USA 104: 4990-4995. https://doi.org/10.1073/pnas.0610045104 
Chaves, M.M., Pereira, J.S., Maroco, J., Rodrigues, M.L., Ricardo, C.P.P., Osório, M.L., Carvalho, I., Faria, T. \& Pinheiro, C. 2002. How plants cope with water stress in the field. Photosynthesis and growth. Annals of Botany 89: 907-916. https://doi.org/10.1093/ aob/mcf105

Classen, A.T., Sundqvist, M.K., Henning, J.A., Newman, G.S., Moore, J.A.M., Cregger, M.A., Moorhead, L.C. \& Patterson, C.M. 2015. Direct and indirect effects of climate change on soil microbial and soil microbial-plant interactions: What lies ahead? Ecosphere 6: 130. https://doi.org/10.1890/ES15-00217.1

Dijkstra, F.A., Hobbie, S.E., Reich, P.B. \& Knops, J.M. H. 2005. Divergent effects of elevated $\mathrm{CO}_{2}$, N fertilization, and plant diversity on soil $\mathrm{C}$ and $\mathrm{N}$ dynamics in a grassland field experiment. Plant Soil 272: 41-52. https://doi.org/10.1007/s11104-004-3848-6

Donatelli, M., Srivastava, A.M., Duveiller, G., Niemeyer, S. \& Fumagalli, D. 2015. Climate change impact and potential adaptation strategies under alternate realizations of climate scenarios for three major crops in Europe. Environmental Research Letter 10: 075005. https://doi.org/10.1088/1748-9326/10/7/075005

Franks, P.J., Adams, M.A., Amthor, J.S., Barbour, M.M., Berry, J.A., Ellsworth, D.S., Farguhar, G.D, Ghannoum, O., Lloyd, J., McDowell, N., Norby, R.J., Tissue, D.T. \& Caemmerer, S. 2013. Sensitivity of plants to changing atmospheric CO concentration: from the geological past to the next century. New Phytologist 197: 1077-1094. https://doi.org/10.1111/nph.12104

Frenck, G., Linden, L., Mikkelsen, T.N., Brix, H. \& Jørgensen, R.B. 2011. Increased [ $\mathrm{CO}_{2}$ ] does not compensate for negative effects on yield caused by higher temperature and $\left[\mathrm{O}_{3}\right]$ in Brassica napus L. European Journal of Agronomy 35: 127-134. https://doi. org/10.1016/j.eja.2011.05.004

Friedlingstein, P., Cox, P.M., Betts, R.A., Bopp, L., von Bloh, W., Brovkin, V., Cadule, P., Doney, S., Eby, M., Fung, I., Bala, G., John, J., Jones, C.D., Joos, F., Kato, T., Kawamiya, M., Knorr, W., Lindsay, K., Matthews, H.D., Raddatz, T., Rayner, P.J., Reick, C., Roeckner, E., Schnitzler, K.G., Schnur, R., Strassmann, K., Weaver, A.J., Yoshikawa, C. \& Zeng, N.2006. Climate-carbon cycle feedback analysis: results from the C4MIP model intercomparison. Journal of Climate 19: 3337-3353. https://doi.org/10.1175/JCLI3800.1

Ge, Z.M., Zhou, X., Kellomäki, S., Biasi, C., Wang, K.Y., Peltola, H. \& Martikainen, P.J. 2012. Carbon assimilation and allocation $\left({ }^{13} \mathrm{C}\right.$ labeling) in a boreal perennial grass (Phalaris arundinacea) subjected to elevated temperature and $\mathrm{CO}_{2}$ through a growing season. Environmental and Experimental Botany 75: 150-158. https://doi.org/10.1016/j.envexpbot.2011.09.008

Gough, C.M., Flower, C.E., Vogel, C.S., Dragoni, D. \& Curtis, P.S. 2009. Whole-ecosystem labile carbon production in a north temperate deciduous forest. Agricultural and Forest Meteorology 149: 1531-1540. https://doi.org/10.1016/j.agrformet.2009.04.006

Gougoulias, C., Clark, J.M. \& Shaw, L.J. 2014. The role of soil microbes in the global carbon cycle: tracking the below-ground microbial processing of plant-derived carbon for manipulating carbon dynamics in agricultural systems. Journal of the Science of Food and Agriculture 94: 2362-2371. https://doi.org/10.1002/jsfa.6577

Heath, J., Ayres, E., Possell, M., Bardgett, R.D., Black, H.I.J., Grant, H., Ineson, P. \& Kerstiens, G. 2005. Rising atmospheric $\mathrm{CO}_{2}$ reduces sequestration of root-derived soil carbon. Science 309: 1711-1713. https://doi.org/10.1126/science.1110700

Hill, P.W., Marshall, C., Williams, G.G., Blum, H., Harmens, H., Jones, D.L. \& Farrar, J.F. 2007. The fate of photosynthetically - fixed carbon in Lolium perenne grassland as modified by elevated $\mathrm{CO}_{2}$ and sward management. New Phytologist 173: 766-777. https:// doi.org/10.1111/j.1469-8137.2007.01966.x

Hungate, B.A., Holland, E.A., Jackson, R.B., Chapin, F.S., Mooney, H.A. \& Field, C.B. 1997. The fate of carbon in grasslands under carbon dioxide enrichment. Nature 388: 576-579. https://doi.org/10.1038/41550

Hungate, B.A., Johnson, D.W., Dijkstra, P., Hymus, G., Stiling, P., Megonigal, J.P., Pagel, A.L., Moan, J.L., Day, F., Li, J., Hinkle, C.R. \& Drake, B.G. 2006. Nitrogen cycling during seven years of atmospheric $\mathrm{CO}_{2}$ enrichment in a scrub oak woodland. Ecology 87: 26-40. https://doi.org/10.1890/04-1732

Jackson, R.B., Lajtha, K., Crow, S.E., Hugelius, G., Kramer, M.G. \& Piñeiro, G. 2017. The Ecology of Soil Carbon: Pools, Vulnerabilities, and Biotic and Abiotic Controls. Annual Review Of Ecology, Evolution, and Systematics 48: 419-445. https://doi.org/10.1146/ annurev-ecolsys-112414-054234

Juknys, R., Duchovslis, P., Sliesaravičius, A., Šlepetys, J., Januškaitienè, I., Brazaitytė, A., Ramaškevičienè, A., Lazauskas, S., Dèdelienė, K., Sakalauskaitè, J., Juozaitytè, R., Kadžiulienè, Ž. \& Dikšaitytė, A. 2011. Response of different agricultural plants to elevated $\mathrm{CO}_{2}$ and air temperature. Žemdirbystè-Agriculture 98: 259-266.

Juknys, R., Januškaitienè, I., Dikšaitytè, A. \& Šliumpaitè, I. 2012. Impact of warming climate on barley and tomato growth and photosynthetic pigments. Biologija 58: 87-97. https://doi.org/10.6001/biologija.v58i2.2490

Juknys, R., Velička, R., Kanapickas, A., Kriaučiūnienè, Z., Masilionytè, L., Vagusevičienė, I., Pupalienė, R., Klepeckas, M. \& Sujetovienè, G. 2017. Projecting the impact of climate change on phenology of winter wheat in northern Lithuania. International Journal of Biometeorology 61: 1765-1775. https://doi.org/10.1007/s00484-017-1360-y

Kacienė, G., Dikšaitytė, A., Januškaitienè, I., Miškelytė, D., Žaltauskaitè, J., Sujetovienè, G., Sakalauskienè, S., Miliauskienė, J., Juozapaitienè, G. \& Juknys, R. 2017. Different Crop and Weed Performance under Single and Combined Effects of Elevated $\mathrm{CO}_{2}$ and Temperature. Crop Science 57: 1-10. https://doi.org/10.2135/cropsci2016.07.0598

Kant, S., Seneweera, S., Rodin, J., Materne, M., Burch, D., Rothstein, S.J. \& Spangenberg, G. 2012. Improving yield potential in crops under elevated $\mathrm{CO}_{2}$ : integrating the photosynthetic and nitrogen utilization efficiencies. Frontiers in Plant Science 3: 1-9. https://doi.org/10.3389/fpls.2012.00162

Kaplan, F., Zhao, W., Richards, J.T., Wheeler, R.M., Guy, C. L. \& Levine, L.H. 2012. Transcriptional and metabolic insights into the differential physiological responses of Arabidopsis to optimal and supraoptimal atmospheric CO. PLoS One 7: e43583. https:// doi.org/10.1371/journal.pone.0043583

Körner, C. 2006. Plant CO responses: an issue of definition, time and resource supply. New Phytologist 172: 393-411. https:// doi.org/10.1111/j.1469-8137.2006.01886.x

Kuzyakov, Y. \& Domanski, G. 2000. Carbon input by plants into the soil. Review. Journal of Plant Nutrition and Soil Science 163 : 421-431. https://doi.org/10.1002/1522-2624(200008)163:4<421::AID-JPLN421>3.0.CO;2-R 
Lawlor, D.W. \& Mitchell, R.A.C. 2000. Crop ecosystem responses to climatic change: wheat. In: Reddy, K.R. \& Hodges, H.F. (eds.). Climate Change and Global Crop Productivity. Wallingford: CABI Publishing. p. 57-80. https://doi.org/10.1079/9780851994390.0057

Leakey, A.D.B., Ainsworth, E.A., Bernacchi, C.J., Rogers, A., Long, S.P. \& Ort, D.R. 2009. Elevated CO effects on plant carbon, nitrogen, and water relations: six important lessons from FACE. Journal of Experimental Botany 60: 2859-2876. https://doi. org/10.1093/jxb/erp096

Li, P., Ainsworth, E.A., Leakey, A.D., Ulanov, A., Lozovaya, V., Ort, D.R. \& Bohnert, H.J. 2008. Arabidopsis transcript and metabolite profiles: ecotype-specific responses to open-air elevated [ $\mathrm{CO}_{2}$ ]. Plant, Cell and Environment 31: 1673-1687. https://doi. org/10.1111/j.1365-3040.2008.01874.x

Long, S.P. \& Drake B.G. 1991. Effect of the long-term elevation of $\mathrm{CO}_{2}$ concentration in the field on the quantum yield of photosynthesis of the $C_{3}$ sedge, Scirpus olneyi. Plant Physiology 96: 221-226. https://doi.org/10.1104/pp.96.1.221

Long, S.P., Ainsworth, E.A., Rogers, A. \& Ort, D.R. 2004. Rising atmospheris carbon dioxide: plants FACE the future. Annual Review of Plant Biology 55: 591-628. https://doi.org/10.1146/annurev.arplant.55.031903.141610

Ludewig, F. \& Flügge, U.I. 2013. Role of metabolite transporters in source-sink carbon allocation. Frontiers in Plant Science 4: 231. https://doi.org/10.3389/fpls.2013.00231

Mathew, I., Shimelis, H., Mutema, M. \& Chaplot, V. 2017. What crop type for atmospheric carbon sequestration: Results from a global data analysis. Agriculture, Ecosystems and Environment 243: 34-46. https://doi.org/10.1016/j.agee.2017.04.008

McMurtrie, R.E. \& Wang, Y.P. 1993. Mathematical models of the photosynthetic response of tree stands to rising CO ${ }_{2}$ concentrations and temperature. Plant, Cell and Environment 16: 1-13. https://doi.org/10.1111/j.1365-3040.1993.tb00839.x

Nowak, R.S., Ellsworth, D.S. \& Smith, S.D. 2004. Functional responses of plants to elevated atmospheric CO - do photosynthetic and productivity data from FACE experiments support early predictions? New Phytologist 162: 253-280. https://doi.org/10.1111/ j.1469-8137.2004.01033.x

Pausch, J. \& Kuzyakov, Y. 2017. Carbon input by roots into the soil: Quantification of rhizodeposition from root to ecosystem scale. Global Change Biology 24: 1-12. https://doi.org/10.1111/gcb.13850

Pendall, E. 2004. Below-ground process responses to elevated $\mathrm{CO}_{2}$ and temperature: a discussion of observations, measurement methods, and models. New Phytologist 162: 311-322. https://doi.org/10.1111/j.1469-8137.2004.01053.x

Rasse, D.P., Rumpel, C. \& Dignac, M.F. 2005. Is soil carbon mostly root carbon? Mechanisms for a specific stabilization. Plant and Soil 269: 341-356. https://doi.org/10.1007/s11104-004-0907-y

Rayner, P.J., Scholze, M., Knorr, W., Kaminski, T., Giering, R. \& Widmann, H. 2005. Two decades of terrestrial carbon fluxes from a carbon cycle data assimilation system (CCDAS). Global Biogeochemical Cycles 19: 20-26. https://doi.org/10.1029/2004GB002254

Richardson, A.D., Carbone, M.S., Keenan, T.F., Czimczik, C.I., Hollinger, D.Y., Murakami, P., Schaberg, P.G. \& Xu, X. 2013. Seasonal dynamics and age of stemwood nonstructural carbohydrates in temperate forest trees. New Phytologist 197: 850-861. https:// doi.org/10.1111/nph.12042

Sanaullah, M., Chabbi, A., Rumpel, C. \& Kuzyakov, Y. 2012. Carbon allocation in grassland communities under drought stress followed by ${ }^{14} \mathrm{C}$ pulse labeling. Soil Biology and Biochemistry 55: 132-139. https://doi.org/10.1016/j.soilbio.2012.06.004

Taub, D.R. \& Wang, X. 2013. Effects of Carbon Dioxide Enrichment on Plants. Climate Vulnerability 4: 35-50. https://doi.org/10.1016/ B978-0-12-384703-4.00404-4

Tcherkez, G.G.B., Farquhar, G.D. \& Andrews T.J. 2006. Despite slow catalysis and confused substrate specificity, all ribulose bisphosphate carboxylases may be nearly perfectly optimized. Proceedings of the National Academy of Sciences of the USA 103: 7246-7251. https://doi.org/10.1073/pnas.0600605103

Vu, J.C.V. 2005 Acclimation of peanut (Arachis hypogaea L.) leaf photosynthesis to elevated growth CO and temperature. Environmental and Experimental Botany 53: 85-95. https://doi.org/10.1016/j.envexpbot.2004.03.006

Weiner, J. 2004. Allocation, plasticity and allometry in plants. Perspectives in Plant Ecology, Evolution and Systematics 6: $207-215$. https://doi.org/10.1078/1433-8319-00083

Wu, Y.B., Tan, H.C., Deng, Y.C., Wu, J., Xu, X.L., Wang, Y.F., Tang, Y.H., Higashi, T. \& Cui, X.Y. 2010. Partitioning pattern of carbon flux in a Kobresia grassland on the Qinghai - Tibetan Plateau revealed by field ${ }^{13} \mathrm{C}$ pulse-labeling. Global Change Biology $16: 2322-$ 2333. https://doi.org/10.1111/j.1365-2486.2009.02069.x

Xu, Z., Jiang, Y. \& Zhou, G. 2015. Response and adaptation of photosynthesis, respiration, and antioxidant systems to elevated CO 2 with environmental stress in plants. Frontiers in Plant Science 6: 701. https://doi.org/10.3389/fpls.2015.00701

Yoon, S.T., Hoogenboom, G., Flitcroft, I. \& Bannayan, M. 2009. Growth and development of cotton (Gossypium hirsutum L.) in response to $\mathrm{CO}$ enrichment under two different temperature regimes. Environmental and Experimental Botany 67: $178-187$. https://doi.org/10.1016/j.envexpbot.2009.06.015

Zweifel, R., Zeugin, F., Zimmermann, L. \& Newbery, D.M. 2006. Intra-annual radial growth and water relations of trees - implications towards a growth mechanism. Journal of Experimental Botany 57: 1445-1459. https://doi.org/10.1093/jxb/erj125 